Estuarine, Coastal and Shelf Science

September 2016, Volume 179, Pages 4-11

http://dx.doi.org/10.1016/i.ecss.2016.01.024

http://archimer.ifremer.fr/doc/00309/42061/

(C) 2016 Elsevier Ltd. All rights reserved.

\title{
Carbon sequestration loss following Zostera noltei decline in the Arcachon Bay (France)
}

\author{
Ribaudo Cristina ${ }^{1,{ }^{*}}$, Plus Martin ${ }^{2}$, Ganthy Florian ${ }^{1}$, Auby Isabelle ${ }^{1}$
}

${ }^{1}$ IFREMER, DEL/AR, Quai du Cdt Silhouette, 33120 Arcachon, France

2 IFREMER, Centre Bretagne, ZI de la Pointe du Diable, 29280 Plouzané, France

* Corresponding author: Cristina Ribaudo, Tel.: +33 05578908 55; fax: +33 05578908 01. ;

mail address : cristina.ribaudo@irstea.fr

\begin{abstract}
:
The worldwide decline of seagrass meadows may result in the loss of relevant ecosystem services such as the carbon sequestration within marine ecosystems. In this paper, net primary production (NPP) of Zostera noltei meadows was assessed in the Arcachon Bay (SW France) with the aim of understanding the impact of meadows decline on $\mathrm{C}$ sequestration capacity at a basin scale. Net growth rates obtained by means of a year-long leaf-marking experiment (2005-2006) were coupled to interannual biomass measurements (1983-2010) to obtain a direct estimate of NPP. Concurrently, an indirect estimate was obtained through a mathematical model which embedded natural factors variation (temperature, light and nutrients). Z. noltei seasonal growth and leaf morphometry followed a unimodal pattern with a peak in late summer and a minimum in winter; the interannual biomass assessment showed a steadiness at spatial and temporal scales. Net primary production simulated by the mathematical model resulted lower than that obtained by the leaf-marking and biomass method. Moreover, a temporal shift among models was evident, given to the dependence of the simulation mainly on the irradiance. Daily NPP ranged from $0.4 \pm 0.2$ to $8.4 \pm 0.4 \mathrm{gDW} \mathrm{m}-2 \mathrm{~d}-1$, corresponding to an annual NPP of $1134.2 \pm 100.2$ gDW m-2y-1 and to a net $C$ fixation of $362.9 \pm 88.1 \mathrm{~g} \mathrm{C} \mathrm{m-2y-1.} \mathrm{By} \mathrm{considering} \mathrm{the} \mathrm{decline} \mathrm{of} 33 \%$ of $Z$. noltei meadows in the Arcachon Bay in the period 1989-2010, it can be estimated a loss of $C$ sequestration capacity from $24846 \pm 6030$ ton $C y-1$ (1989) to $16564 \pm 4020$ ton $C y-1$ (2007) at the basin scale.
\end{abstract}

Keywords : Seagrass, Meadow regression, Macrotidal lagoon, Growth model, Nutrient leaf resorption 


\section{Introduction}

As a result of their elevated primary production, seagrass meadows stock large amounts of organic and inorganic $\mathrm{C}$ and act as an important sink for the global $\mathrm{C}$ budget (Fourqurean et al., 2012). The decline of seagrass meadows constitutes thus a threat for $\mathrm{C}$ sequestration that needs to be quantified (Valle et al., 2014). Besides their intrinsic primary production (Duarte and Chiscano, 1999), seagrasses host highly productive epiphyte communities on their leaves (Ouisse et al., 2010) and favor aerobic microbial processes within their rhizosphere thanks to sediment oxygenation (Welsh et al., 2000). As a consequence, rooted marine vegetation contributes to slow down carbon recycling and its availability in the system, contrary to what happens in macroalgae-dominated systems (Duarte et al., 2005; Viaroli et al., 2008; Montefalcone et al., 2015).

Seagrass C sequestration can be assessed by a number of indirect methods, by coupling ecological traits of the plant ( $\mathrm{C}$ content, biomass, leaf turnover) to punctual measurements of the ecosystem processes (benthic chambers, harvesting method, eddy covariance, core incubations) (Auby and Labourg, 1996; Welsh et al., 2000; Polsenaere et al., 2012; Ouisse et al., 2010; Clavier et al., 2014). However, direct measurements of primary production are often required to ameliorate estimates. For instance, NPP measured by the leaf-marking technique (Zieman, 1974; Sand-Jensen, 1975) can be combined to indirect measurements to obtain additional knowledge of benthic production/respiration processes (Welsh et al., 2000; Pinardi et al., 2009; Ouisse et al., 2010; Ribaudo et al., 2011). Direct measurements of productivity also allow avoiding the bias of immersion/emersion short-term measurements (Polsenaere et al., 2012; Ouisse et al., 2014; Clavier et al., 2014). In macrotidal coastal systems, seagrass meadows are indeed submitted to significant emersion periods, which may influence their productivity and seasonal dynamics. For example, the inhibition of primary production has been reported during emersion by Clavier et al. (2011) and Ouisse et al. (2011), that probably due to photoinhibition or desiccation (Leuschner et al., 1998). This is why, even if permanently-submerged seagrasses show physiological patterns coincident with temporal variation of environmental factors 
(Mascaró et al., 2014), this could not be the case for intertidal seagrasses, which might rather be limited during the period of maximal irradiation (Leuschner et al., 1998; Ouisse et al., 2010). This could also have implications on the productivity simulations based on environmental variables patterns (Plus et al., 2003; Plus et al., 2009; Valle et al., 2014).

Since 1984, many investigations have been realized on the seagrass meadow of the tidal flats of Arcachon Bay (south-western coast of France); the number of studies has recently risen because of the diminution of the vegetated surface (Plus et al., 2010; Fourqurean et al., 2012). In order to assess the impact of eelgrass meadows decline on C sequestration, Z. noltei shoot growth and dynamics were assessed on a seasonal basis and coupled to interannual biomass measurements. This allowed i) describing Z. noltei physiological patterns in relationship with local environmental factors fluctuations and ii) obtaining an estimate of Z. noltei NPP at the basin scale. Additionally, an indirect estimate of NPP was obtained through a mathematical model and allowed iii) verifying the reliability of an indirect method based on local environmental factors fluctuations.

\section{Materials and methods}

\subsection{Study area}

The Arcachon Bay is a $155 \mathrm{~km}^{2}$ shallow lagoon located in the southern Atlantic Coast of France. Here, tidal amplitude ranges from $1.10 \mathrm{~m}$ at neap tide to $4.95 \mathrm{~m}$ at spring tide and local mean sea level (MSL) is at $2.20 \mathrm{~m}$ above chart datum. Within the bay, perennial monospecific meadows of Zostera noltei (Z. noltei; Hornemann, 1832) cover about half of the total flat surface, for a surface estimated at $45.7 \mathrm{~km}^{2}$ in 2007 , whereas Zostera marina meadows cover only a small area, estimated at $1.0 \mathrm{~km}^{2}$ in 2008 (Auby and Labourg, 1996; Plus et al., 2010). Brackish macrophytes such as Ruppia cirrhosa and some macroalgae such as Enteromorpha spp., Ulva sp. and Gracilaria verrucosa also occur within the bay, but typically on different habitats than those colonised by eelgrasses (Auby et al., 1993; Auby et al., 2011). 


\subsection{Net growth rates and biomass measurements}

In this study, we combined results of an annual leaf-marking performed at one site to biomass measurements performed during many years at different locations of the bay (Table 1 and figure 1). From May 2005 to May 2006, Z. noltei net growth rates (NGR) were measured by means of the leaf-marking technique (Zieman, 1974; Sand-Jensen, 1975; Vermaat et al., 1987; Philippart, 1995 ) within a homogenous meadow positioned in the southern part of the bay (coord: $44^{\circ} 39.3^{\prime}$ $\left.\mathrm{N}, 1^{\circ} 08.4^{\prime} \mathrm{W}\right)$. At each sampling, an area of $27 \times 27 \mathrm{~cm}$ was delimited within the meadow; here, 30 to 40 randomly selected shoots were carefully marked by means of a needle at the sheath apex. After marking, plants were left in situ for an exposure time of $4-9$ days, the longer period being during winter. The length of the exposure time was chosen following the observed leaves renewal, in order to minimize leaf loss, according to the assumption that an old leaf is lost in conjunction with the appearance of a new one (Sand-Jensen, 1975). At the retrieval, plants were transported into a refrigerated box to the laboratory; in the meanwhile, a new area of the meadow was delimited and new shoots were marked.

In laboratory, plants were gently washed and immediately sorted for marked shoots. For each marked shoot, each leaf was measured from the sheath to the needle mark and then till the apex. We considered that the leaf had grown when the distance between the sheath and the mark was $>0$; leaves that did not present any mark were considered as new born. Shoot growth derived from the sum of the surface increase of each single leaf within the shoot. Conversion of surface to biomass increase was obtained from Specific Leaf Area (SLA, $\mathrm{cm}^{2} \mathrm{~g}_{\mathrm{DW}}{ }^{-1}$ ) which resulted from the measure of surface and dry weight of a subset of leaves $\left(70{ }^{\circ} \mathrm{C}\right.$ during 48 hours, $\mathrm{n}=60$ at each sampling). Aboveground NGR was calculated assuming an exponential growth and

expressed as $\mathrm{g}_{\mathrm{DW}} \mathrm{g}_{\mathrm{DW}}{ }^{-1} \mathrm{~d}^{-1}$ (Zieman, 1974; Sand-Jensen, 1975; Vermaat et al., 1987). Leaf appearance rate (LAR, new leaves shoot ${ }^{-1} \mathrm{~d}^{-1}$ ) was calculated according to the number of new leaves appeared per shoot during the exposure period; leaf lifespan (days) was calculated as the inverse of leaf appearance rate. Shoot lifespan (days) was calculated from the leaf lifespan 
multiplied by the number of leaves per shoot. Shoot weight $\left(\mathrm{mg}_{\mathrm{DW}}\right)$ was given by the sum of the surface of the leaves of each shoot multiplied by the corresponding SLA.

Biomass harvesting was performed between 1983 and 2010 by cores collection at different sites of the bay (Table 1 and figure 1). At each site, above- (leaves) and belowground (roots + rhizomes) biomass was measured and expressed as $\mathrm{g}_{\mathrm{Dw}} \mathrm{m}^{-2}$ (Auby and Labourg, 1996; Welsh et al., 2000; Auby et al., 2011; Ganthy et al., 2013).

\subsection{Influence of local environmental factors on NGR}

From May 2005 to May 2006, water temperature $\left({ }^{\circ} \mathrm{C}\right)$ was measured in continuum by a sensor (Seamon-mini HugrunTM, accuracy $\pm 0.1{ }^{\circ} \mathrm{C}$ ) positioned in the water near the leaf-marking site, while air temperature $\left({ }^{\circ} \mathrm{C}\right)$ and irradiance $\left(\mathrm{W} \mathrm{m}^{-2} \mathrm{~d}^{-1}\right)$ were provided by Météo France weather station located at Lège Cap-Ferret. Photoperiod was calculated according to the formula proposed by Forsythe et al. (1995). Further, we tested the regression between environmental factors (air, water temperature and irradiance) and NGR by means of a stepwise backward regression. The best model was selected by minimizing the Akaike Information Criterion (AIC); its predictive performance was then assessed using a 10 -fold cross-validation. Statistics were performed using the "mass" and "bootstrap" packages of the R software (R Core Team, 2014).

\subsection{NPP assessed by means of leaf-marking and biomass method}

Daily net primary production $\left(\mathrm{NPP}_{\mathrm{D}}, \mathrm{g}_{\mathrm{DW}} \mathrm{m}^{-2} \mathrm{~d}^{-1}\right)$ based on direct measurements of growth rate and biomass was calculated as follows:

$\mathrm{NPP}_{\mathrm{D}}=\mathrm{NGR}($ month $) \times$ Biomass (month)

Where NGR (month) indicates the average NGR value measured on the month $\mathrm{X}\left(\mathrm{g}_{\mathrm{DW}} \mathrm{g}_{\mathrm{DW}}{ }^{-1} \mathrm{~d}^{-1}\right)$ during the period 2005-2006, Biomass (month) indicates the average biomass value measured on the month $\mathrm{X}\left(\mathrm{g}_{\mathrm{DW}} \mathrm{m}^{-2}\right)$ during the period 1983-2010. Further, $\mathrm{NPP}_{\mathrm{D}}$ calculated for each month were multiplied by a C content of $0.32 \mathrm{~g} \mathrm{C} \mathrm{g}_{\mathrm{Dw}}{ }^{-1}$ in the Z. noltei leaves, (Pérez-Lloréns and Niell, 1993; Plus et al., 2001) in order to obtain an estimation of net C fixation, and were 
expressed as $\mathrm{g} \mathrm{C} \mathrm{m}^{-2} \mathrm{~d}^{-1}$. NPP calculated for each month were then summed and upscaled to the entire year. Annual nitrogen and phosphorous resorption were also estimated by considering an aboveground $\mathrm{N}$ content of $0.03 \mathrm{~g} \mathrm{~N} \mathrm{~g}_{\mathrm{DW}}{ }^{-1}$ and a $\mathrm{P}$ content of $0.007 \mathrm{~g} \mathrm{P}_{\mathrm{DW}}{ }^{-1}$ (van Lent et al., 1991; Péréz-Lloréns and Niell, 1993; Kraemer and Mazzella, 1999; Plus et al., 2001; Peralta et al., 2005).

\subsection{NPP assessed by means of a mathematical model}

Net primary production obtained by leaf-marking and biomass measurements was then compared to simulated values obtained using a mathematical model. The model we used, MARS-3D (Model for Applications at Regional Scale), fully couples ecology with hydrodynamics. A detailed description of this model was published in Lazure and Dumas (2008) and it has been already applied to the Arcachon Bay: in Glé et al. (2007) and Plus et al. (2009) for hydrodynamic applications, and in Kombiadou et al. (2014) for sediment dynamics purposes. The ecological model is a classical NPZD model (Nutrient-PhytoplanktonZooplankton-Detritus) coupled with equations for Z. noltei growth. All biogeochemical equations as well as their parameterization were previously detailed in several works - Loyer (2001) and Huret et al. (2013) for the biogeochemical cycling and the planktonic network, Plus et al. (2003) for the Z. noltei sub-model - and can be consulted on the MARS-3D technical documentation (IFREMER-Dyneco, 2012, http://wwz.ifremer.fr/mars3d).

The model limits are $44^{\circ} 21^{\prime} \mathrm{N}-44^{\circ} 54^{\prime} \mathrm{N}$ and $0^{\circ} 57^{\prime} \mathrm{W}-1^{\circ} 27^{\prime} \mathrm{W}$, with a spatial horizontal resolution of $235 \mathrm{~m}$ (squared grid) and 10 layers on the vertical. It is forced at the boundaries for free surface elevation, water temperature and salinity by another model (Lazure et al., 2009), which simulates the Bay of Biscay hydrodynamics. Realistic atmospheric conditions throughout the domain (air temperature, atmospheric pressure, nebulosity, relative humidity) were provided by the Arpege Météo-France model (Déqué et al., 1994). The model bathymetry resulted from combined datasets: L'Yavanc (1995) for the Arcachon lagoon, the SMNG (Service Maritime de Navigation de la Gironde) for the sandy inlets area, and the SHOM (Service Hydrographique et 
Océanographique de la Marine) for the open ocean. Continental (nutrients) and hydrological (suspended sediment) inputs were respectively supplied by the HYDRO database and the Arcachon Bay hydrological network (Ifremer-ARCHYD).

Z. noltei meadows daily net primary production $\left(\mathrm{NPP}_{\mathrm{IND}}\right)$ was calculated all along the study period (2005 and 2006) and all over the Arcachon Bay, by taking into account the incoming light at the canopy level, the nitrogen and phosphorus internal quotas, and the water temperature:

$N P P_{\text {LND }}=P_{\max }^{O^{\circ} \mathrm{C}} \cdot f_{\text {Temp }} \cdot \min \left(f_{\text {hum }}, Q_{N}, Q_{P}\right)-$ Resp $^{O^{\circ} C_{1}} \cdot f_{\text {Temp }}$

With $P_{\max }^{\circ} \mathrm{C}$ and $R e s p^{\circ} \mathrm{C}$ the respective theoretical maximum production and respiration at $0^{\circ} \mathrm{C}$, $f_{\text {Temp }}$, the production/respiration increase with temperature (an exponential formulation, according to Eppley, 1972 and Plus et al., 2005), flum, the light limitation function (Jassby and Platt, 1976), $\mathrm{Q}_{\mathrm{N}}$ and $\mathrm{Q}_{\mathrm{P}}$, the limitation function due to nitrogen and phosphorus internal quotas (Droop's model, 1973). Initialization of Z. noltei meadows in the model's meshes was performed according to the year 2005 extension map published in Plus et al. (2010). Every day, the total NPP calculated for all meshes containing Z. noltei meadows was pooled in order to calculate mean and interquartile range.

\section{Results}

\subsection{Net growth rates and local environmental factors}

Shoot morphometry and growth measurements were performed on a total of 660 shoots and of 2072 leaves. In general, growth indicators (NGR, LAR, SLA, leaf lifespan) followed a unimodal pattern, with a maximum in late summer (late August and early September) and a minimum in winter (February). NGR varied between $0.01 \pm 0.00$ and $0.09 \pm 0.00 \mathrm{~g}_{\mathrm{DW}} \mathrm{g}_{\mathrm{DW}}{ }^{-1} \mathrm{~d}^{-1}$ (Figure 3). Daily temperature values in 2005-2006 ranged from -1.4 to $28.5^{\circ} \mathrm{C}$ and from 4.2 to $23.8^{\circ} \mathrm{C}$, for air and water, respectively. Water temperature was significantly dependent on the air temperature $\left(\mathrm{R}^{2}=0.94, p<0.001\right)$. Daily irradiance values were comprised between 577.4 
and $8365.5 \mathrm{~W} \mathrm{~m}^{-2} \mathrm{~d}^{-1}$; photoperiod ranged from $8.6 \mathrm{~h}$ in December to $15.4 \mathrm{~h}$ in June (Figure 2). Irradiance was significantly dependent on the photoperiod $\left(\mathrm{R}^{2}=0.60, p<0.01\right)$.

The stepwise regression excluded the variable "air temperature" from the model (initial model, AIC $=-5148.80$; final model, AIC $=-5150.74)$. The best regression model $(\mathrm{F}=90.2$ on 3 and 656 degree of freedom; $p<0.001$ ) was obtained using water temperature (WTEMP) and the interaction between irradiance (IRR) and water temperature as predictive variables:

$\mathrm{NGR}=\mathrm{a} \cdot \mathrm{WTEMP}+\mathrm{b} \cdot$ WTEMP $\mathrm{x}$ IRR

Where $\mathrm{a}=4.44 \times 10^{-3}$ and $\mathrm{b}=-2.97 \times 10^{-3}$. The model explained $29.2 \%$ of the NGR variability.

LAR was comprised between $0.01 \pm 0.01$ and $0.25 \pm 0.02$ new leaves $\operatorname{shoot}^{-1} \mathrm{~d}^{-1}$ (Figure 4). SLA varied between $320.5 \pm 29.5$ and $666.6 \pm 15.1 \mathrm{~cm}^{2} \mathrm{~g}_{\mathrm{DW}}{ }^{-1}$ (Figure 4). Biomass allocated on new leaves constituted from 3 (February) to $45 \%$ (August) of the total new born biomass; consistently, leaf lifespan presented a minimum of $4.0 \pm 0.3$ days in August and a maximum of $77.3 \pm 1.2$ days in February (overall average: $17.4 \pm 2.6$ days). Shoot lifespan was comprised between $14.8 \pm 0.5$ and $160.9 \pm 3.2$ days (overall average: $50.2 \pm 5.6$ days), corresponding to an average shoot turnover of $9.5 \pm 0.8 \mathrm{y}^{-1}$.

With some exceptions, leaf morphometry was affected by an elevated variability and mean values remained steady along the year. Number of leaves per shoot was comprised between 2.1 \pm 0.1 and $3.7 \pm 0.2$ (overall average: $3.1 \pm 0.7$ ). Shoot weight was comprised between $2.1 \pm 0.1$ and $10.9 \pm 0.7 \mathrm{mg}_{\mathrm{DW}}$, the lowest values being measured during summer (overall average: $7.3 \pm$ $3.1 \mathrm{mg}_{\mathrm{DW}}$ ). Canopy height varied between $5.9 \pm 0.4$ and $13.5 \pm 0.9 \mathrm{~cm}$ (overall average: $9.5 \pm$ $0.1 \mathrm{~cm}$ ); max leaf width was comprised between $0.8 \pm 0.0$ and $1.7 \pm 0.0 \mathrm{~mm}$ (overall average: $1.2 \pm 0.0 \mathrm{~mm}$ ). Leaf surface varied between $39.7 \pm 2.7$ and $165.6 \pm 9.4 \mathrm{~mm}^{2}$, the lowest values being measured during summer (overall average: $91.9 \pm 43.3 \mathrm{~mm}^{2}$ ).

\subsection{NPP assessed by means of leaf-marking and biomass method}


Aboveground biomass measured at different sites during different years showed a consistent seasonal pattern, with a peak in late summer $\left(142.7 \pm 16.7 \mathrm{~g}_{\mathrm{Dw}} \mathrm{m}^{-2}\right.$ measured in September 2010) and a minimum in winter $\left(7.2 \pm 3.1 \mathrm{~g}_{\mathrm{DW}} \mathrm{m}^{-2}\right.$ measured in January 2010$)$; belowground biomass showed an irregular pattern with values ranging between $24.7 \pm 17.1$ and $494.8 \pm 258.6$ $\mathrm{g}_{\mathrm{DW}} \mathrm{m}^{-2}$ (Figure 5). When coupled to monthly biomass measurements, seasonal NGR allowed estimating a daily $\mathrm{NPP}_{\mathrm{D}}$ ranging from $0.4 \pm 0.2$ to $8.4 \pm 0.4 \mathrm{~g}_{\mathrm{DW}} \mathrm{m}^{-2} \mathrm{~d}^{-1}$, equivalent to an annual $\mathrm{NPP}_{\mathrm{D}}$ of $1134.2 \pm 100.2 \mathrm{~g}_{\mathrm{Dw}} \mathrm{m}^{-2} \mathrm{y}^{-1}$. Mean $\mathrm{NPP}_{\mathrm{D}}$ expressed as $\mathrm{C}$ fixation was comprised between $0.05 \pm 0.09$ and $2.62 \pm 1.71 \mathrm{~g} \mathrm{C} \mathrm{m}^{-2} \mathrm{~d}^{-1}$ (Figure 6), corresponding to an annual net $\mathrm{C}$ fixation of $362.9 \pm 88.1 \mathrm{~g} \mathrm{C} \mathrm{m}^{-2} \mathrm{y}^{-1}$ and to an annual nutrient leaf resorption of $34.0 \pm 8.3 \mathrm{~g} \mathrm{~N} \mathrm{~m}^{-}$ ${ }^{2} \mathrm{y}^{-1}$ and $7.9 \pm 1.9 \mathrm{~g} \mathrm{P} \mathrm{m}^{-2} \mathrm{y}^{-1}$.

\subsection{NPP assessed by means of a mathematical model}

Simulated daily net primary production $\left(\mathrm{NPP}_{\mathrm{IND}}\right)$ showed a unimodal pattern, for both years, with the productive period running between March and July, followed by a decay period starting in late summer and enduring until February (Figure 7). Yet, according to the model results, the amplitude of Z. noltei NPP IND may have been very different in 2005 and 2006. The calculated production resulted much higher during 2005 , with a maximum occurring on the $26^{\text {th }}$ of June of $2.25 \mathrm{~g} \mathrm{C} \mathrm{m}^{-2} \mathrm{~d}^{-1}$ (interquartile ranging from 1.75 to $2.63 \mathrm{~g} \mathrm{C} \mathrm{m}^{-2} \mathrm{~d}^{-1}$ at the same date), while during year 2006 production did not exceed $1.09 \mathrm{~g} \mathrm{C} \mathrm{m}^{-2} \mathrm{~d}^{-1}$ (the maximum is reached later in the year, the $18^{\text {th }}$ of July 2006 , and interquartile ranged that day from 0.59 to $1.25 \mathrm{~g} \mathrm{C} \mathrm{m}^{-2} \mathrm{~d}^{-1}$ ).

\section{Discussion}

\subsection{Net growth rates and C sequestration}

This study highlights the impact of Z. noltei decline on C sequestration within the intertidal flats of a macrotidal coastal system. When considering the disappearance of about $33 \%$ of $Z$. noltei meadows in the Arcachon Bay (Plus et al., 2010), it can be estimated a decline of C fixation capacity falling from $24846 \pm 6030$ ton $\mathrm{C}^{-1}$ (1989) to $16564 \pm 4020$ ton $\mathrm{C} \mathrm{y}^{-1}$ (2007).This 
result is relevant in the general context of the major role played by rooted submerged vegetation over the phytoplankton compartment in C sequestration (Glé et al., 2008; Polsenaere et al., 2012); secondly, in Archachon Bay eelgrass meadows represent a highly productive system, comparable to that formed by salt marshes of the same area (Soriano-Sierra, 1992). Furthermore, one must consider that other rhizophytes have almost disappeared from the lagoon: Zostera marina is still present in restricted areas and with very low biomasses (Plus et al., 2010; Auby et al., 2011). According to recent studies (Auby et al., 2011), macroalgae are not significantly associated with Z. noltei meadows in Arcachon Bay, so that we can hypothesize that their decline do not impact macroalgal production. On the contrary, the structural degradation of Z. noltei meadows may result in the progressive replacement of eelgrass by opportunistic macroalgae, that potentially affecting ecosystem functioning (Montefalcone et al., 2015).

Net primary production calculated by means of the leaf-marking and biomass method resulted consistent with values obtained via other methods in the same area (Auby and Labourg, 1996; Deborde et al., 2008; Polsenaere et al., 2012; Ouisse et al., 2010) or elsewhere (Vermaat et al., 1987; Pérez-Lloréns and Niell, 1993; Duarte and Chiscano, 1999; Cabaço et al., 2009) for Z. noltei populations. We acknowledge that, especially during the summer, when leaf tips are broken and the fastest leaf turnover occurs, the leaf-marking technique can bring to an underestimation of initial leaf surface considered in the calculation and thus to an overestimation of net growth rates. In our case, this error source was overtaken by reducing the time between samplings and by increasing the number of replicates.

\subsection{Productivity in relationship to measured and simulated environmental factors}

Z. noltei seasonal growth patterns and morphometry in Arcachon Bay resulted consistent to those reported in other temperate sites (van Lent et al., 1991; Cabaço et al., 2009); still, a temporal shift between physiological traits and environmental factors arose from our study, with a growth peak occurring in late summer, a few months later than the maximum values of 
irradiance and photoperiod. Our study evidenced indeed that the unimodal pattern of productivity is associated with an optimal combination of temperature and irradiance and, in general, with water temperature. The correlation between leaf growth rates and water temperature is reported by other authors (Marbá et al., 1996; Kraemer and Mazzella, 1999), together with the evidence that shoots can be stressed when elevated irradiance and air temperature occur simultaneously during emersion (van Lent et al., 1991; Leuschner et al., 1998; Massa et al., 2009). The opposite is shown in studies carried out on permanently submerged seagrasses, such as Cymodocea nodosa and Posidonia oceanica, with a perfect coupling between environmental and physiological patterns (Marbá et al., 1996; Mascaró et al., 2014). Consistently, our results show that, when simulated by a mathematical model, the growth pattern has a temporal shifted peak compared to the measured one: this peak follows indeed irradiance fluctuations. The incongruity between environmental factors and observed growth rate patterns is one of the major limit of the model and brings back to the impracticality of describing meadow dynamics by means of simple relationships, given the complex interaction among leaf dynamics, rhizome elongation, rhizome branching and hydromorphological factors (Duarte and Chiscano, 1999). Moreover, even if results obtained by the leaf-marking and biomass method fall into the range of those resulting from the model, the latter indicates a much lower production during the second year of simulation. When searching for the limitation functions responsible for this low productivity, the model highlights the very low riverine inflows during the winter 2005-2006 and the subsequent simulated low nutrient inputs to the Arcachon Bay, which may have been insufficient to replenish the nutrient quotas of the plants before the growth season. Yet, when looking at the measured nutrients input, both soluble reactive phosphorous (SRP) and dissolved inorganic nitrogen (DIN) show a diminution in summer and an increase during winter during both years (SRP ranging from $0.05 \pm 0.03 \mu \mathrm{M}$ in June 2006 to $0.23 \pm 0.04$ in January 2005; DIN ranging from $0.90 \pm 0.52 \mu \mathrm{M}$ in August 2005 to $31.8 \pm 11.1 \mu \mathrm{M}$ in March 2006). In addition, simulated water temperatures during spring 2006 resulted been lower than in 2005, whereas measured values show a similar trend and values 
along the two years. The difference of simulated productivity between years is thus probably deriving from the crossed action of simulated primary production on different meshes located at different sites and depths, with simulated nutrients input; the model should be probably revised in the light of all these considerations.

\subsection{Seasonal Z. noltei shoot morphometry}

Investigating meadow temporal dynamics is extremely appropriate when considering how seasonality affect the interaction among different parameters. Elevated shoot densities measured in late summer (Auby and Labourg, 1996, Ganthy et al., 2013) are coupled to a low shoot weight and to a low SLA, as a combination of the diminished leaf surface and a reduction of vacuoles dimensions (Peralta et al., 2005; Ribaudo et al., 2011). In the meanwhile, the highest C:N ratio is commonly recorded in the leaf tissue (Pérez-Lloréns and Niell, 1993; Kraemer and Mazzella, 1999) and the fastest leaf turnover occurs. That indicates that, when assessing nutrient budgets with shoot density and turnover as main parameters, a direct measurement of the shoot weight and its SLA needs to be routinely assessed, as substantial temporal and local differences may occur (Cabaço et al, 2009). Besides, little is known about Z. noltei primary production during winter and springtime (Peralta et al., 2005; this study); leaf-marking measurements on $Z$. noltei have been commonly performed between May and October (Vermaat et al., 1987; Philippart, 1995; Marbá et al., 1996) probably given to the difficulty of obtaining suitable replicates within patchy meadows. Our study shows that $Z$. noltei shoots are productive and that new leaves appear even during winter and early springtime at our latitude. That could have relevant implications in the context of net ecosystem metabolism measurements, since wintertime is the period when respiration processes and $\mathrm{C}$ loss from the system are prominent over seagrass primary production (Ouisse et al., 2010; Welsh et al., 2000) and nutrients storage in the aboveground parts is the most pronounced (Pérez-Lloréns and Niell, 1993; Vermaat, 2009). Furthermore, biomass values measured during winter in the Arcachon Bay are 
comparable to those measured at the maximum standing crop at higher latitudes (Vermaat et al., 1987; Philippart, 1995; Duarte and Chiscano, 1999).

\section{Conclusions}

This paper highlights the impact of eelgrasses decline on $\mathrm{C}$ sequestration capacity of a macrotidal coastal system. The loss of Z. noltei meadows in Arcachon Bay deeply modifies C sequestration at the basin scale and should be seriously considered within wildlife conservation actions. Moreover, through the use of different approaches (leaf-marking, biomass harvesting, mathematical model) we demonstrated that the ecophysiology of Z. noltei follows patterns which are spatially and temporally repeatable, yet its modelling by simulated parametrization should be use with care. 
Table 1 Characteristics of the sampling sites of Z. noltei in Arcachon Bay. Tidal level is related to local MSL (tidal coefficient: 40 to 100); mean emersion time is related to the tidal period of meadow exposition to the air. Samples for biomass measurements were collected during different years with different protocols (frequency, sampled surface and number of replicates); leaf-marking was carried out at one site only, yet with higher frequency.

\begin{tabular}{|c|c|c|c|c|c|c|c|c|}
\hline Site & $\begin{array}{l}\text { Tidal } \\
\text { level } \\
\text { (m) }\end{array}$ & $\begin{array}{c}\text { Emersion } \\
\text { time/tide } \\
\text { (h:min) }\end{array}$ & Period of sampling & Sampling frequency & $\begin{array}{l}\text { Sampling } \\
\text { purpose }\end{array}$ & $\begin{array}{c}\text { Sampled } \\
\text { surface }\left(\mathrm{cm}^{2}\right)\end{array}$ & $\begin{array}{c}\text { Number of } \\
\text { replicates }\end{array}$ & Authors \\
\hline $\mathrm{A}$ & 2.0 & $4: 30$ & \multirow{4}{*}{$\begin{array}{l}\text { Nov. } 1983 \text { - } \\
\text { Jan. } 1985\end{array}$} & \multirow{4}{*}{ Monthly } & & 225 & 4 & \multirow{4}{*}{ Auby and Labourg, 1996} \\
\hline B & 2.2 & $5: 10$ & & & & 225 & 4 & \\
\hline $\mathrm{C}$ & 2.5 & $6: 20$ & & & Blomass & 225 & 4 & \\
\hline $\mathrm{D}$ & 2.0 & $4: 30$ & & & & 225 & 4 & \\
\hline $\mathrm{E}$ & 2.1 & 4:50 & Feb.-Oct. 1997 & Four-monthly & Biomass & 254 & 5 & Welsh et al., 2000 \\
\hline $\mathrm{F}$ & 2.5 & $6: 20$ & Sept.: 2006 - & \multirow{2}{*}{ Once a year } & \multirow{2}{*}{ Biomass } & 64 & 9 & \multirow{2}{*}{ Auby et al., 2011} \\
\hline G & 2.4 & $5: 50$ & 2009 & & & 64 & 9 & \\
\hline $\mathrm{H}$ & 1.8 & $3: 45$ & \multirow{3}{*}{$\begin{array}{l}\text { Feb. 2009- } \\
\text { March } 2010\end{array}$} & \multirow{3}{*}{ Monthly } & \multirow{3}{*}{ Biomass } & 79 & 9 & \multirow{3}{*}{ Ganthy et al., 2013} \\
\hline I & 1.7 & $3: 20$ & & & & 79 & 9 & \\
\hline $\mathrm{J}$ & 1.7 & $3: 20$ & & & & 79 & 9 & \\
\hline K & 2.5 & $6: 20$ & $\begin{array}{c}\text { Feb. 2009- } \\
\text { March 2010 }\end{array}$ & Monthly & Biomass & 79 & 9 & Ganthy, unpublished \\
\hline $\mathrm{L}$ & 2.3 & $5: 30$ & May 2005-May 2006 & Weekly to fortnightly & Leaf-marking & 729 & 1 & This study \\
\hline
\end{tabular}




\section{FIGURES CAPTION}

Figure 1 Site location of the meadow investigated for leaf-marking (site L) and those for biomass collection (sites A to K) in the Arcachon Bay (SW France).

Figure 2 Environmental factors measured during the year-long measurement (May 2005 - May 2006) of Z. noltei growth rates in the Arcachon Bay. Irradiance and temperature values are reported as average values calculated for each leaf-marking period. Photoperiod was calculated for the Arcachon Bay according to formula proposed by Forsythe et al. (1995) and is reported as daily value.

Figure 3 Net growth rates (NGR) measured on Z. noltei shoots in the Arcachon Bay from May 2005 to May $2006(10<\mathrm{n}<54$ for each sampling date).

Figure 4 Z. noltei leaves dynamics and morphometry measured within the Arcachon Bay between May 2005 and May 2006. Leaf appearance rate (LAR, $10<\mathrm{n}<54$; mean \pm SE) and Specific Leaf Area (SLA, $n=60$; mean \pm SE) are reported.

Figure 5 Z. noltei interannual aboveground and belowground biomass measurements performed at different sites of the Arcachon Bay between 1983 and 2010. For each measurement, at least 3 replicates are reported (mean \pm SE); values are taken from Auby and Labourg (1996), Welsh et al. (2000), Auby et al. (2011) and Ganthy et al. (2013).

Figure 6 Z. noltei net primary production (NPP) estimates obtained by crossing net growth rates (NGR) and aboveground biomass measurements.

Figure 7 Simulation of daily Z. noltei net primary production for 2005 and 2006 by means of a mathematical model (Plus et al., 2003; Plus et al. 2009). Measured daily irradiance and water temperature are also reported. 


\section{Acknowledgements}

The present work is funded by IFREMER (Institut Français de Recherche pour l'Exploitation de la Mer) and partly by the Leonardo da Vinci Project 2005 (n. I/04/A/PL/154254-GL - Job Seeker) in collaboration with Marco Bartoli ( University of Parma, Italy). Authors wish to thank B. Gouillieux for participating to field activities.

\section{References list}

Auby, I., Bachelet, G., Labourg P.J., 1993. Biomass and species composition of macrophytes in Arcachon Bay and Prevost lagoon, with a compilation of data of primary production in Arcachon Bay. CLEAN meeting, Alicante, 3-5 December 1993. http://archimer.ifremer.fr/doc/00259/37008/

Auby, I., Labourg, P.J., 1996. Seasonal dynamics of Zostera noltii Hornem. in the Bay of Arcachon (France). J. Sea Res. 35, 269-277

Auby, I., Trut, G., Barbier, C., Bujan, S., Cordier, M., 2011. Suivi stationnel des herbiers de zostères (Zostera noltii et Zostera marina) de la Masse d'eau côtière FRFC06 - Arcachon amont - District Hydrographique Adour-Garonne - 2006-2007-2008-2009. http://archimer.ifremer.fr/doc/00032/14356/

Cabaço, S., Machás, R., Santos, R., 2009. Individual and population plasticity of the seagrass Zostera noltii along a vertical intertidal gradient. Est. Coast. Shelf Sci. 82, 301-308

Clavier, J., Chauvaud, L., Carlier, A., Amice, E., van der Geest, M., Labrosse, P., Diagne, A., Hily, C., 2011. Aerial and underwater carbon metabolism of a Zostera noltii seagrass bed in the Banc d'Arguin, Mauritania. Aquat. Bot. 95, 24-30

Clavier, J., Chauvaud, L., Amice, E., Lazure, P., van der Geest, M., Labrosse, P., Diagne, A., Carlier, A., Chauvaud, S., 2014. Benthic metabolism in shallow coastal ecosystems of the Banc d'Arguin, Mauritania. Mar Ecol Prog Ser 501, 11-23

Deborde, J., Abril, G., Mouret, A., Jézéquel, D., Thouzeau, G., Clavier, J., Bachelet, G., Anschutz, P., 2008. Effects of seasonal dynamics in a Zostera noltii meadow on phosphorus and iron cycles in a tidal mudflat (Arcachon Bay, France). Mar. Ecol. Prog. Ser. $355,59-71$

Déqué, M., Dreveton, C., Braun, A., Cariolle, D., 1994. The ARPEGE-IFS atmosphere model: a contribution to the French community climate modelling. Clim. Dyn. 10, 249-266

Duarte, C.M., Chiscano, C.L., 1999. Seagrass biomass and production: a reassessment. Aquat. Bot. $65,159-174$ 
Duarte, C.M., Middelburg, J.J., Caraco, N., 2005. Major role of marine vegetation on the oceanic carbon cycle. Biogeosciences. 2, 1-8

Eppley, R.W., 1972. Temperature and phytoplankton growth in the sea. Fish. Bull. 70, 10631085

Forsythe, W.C., Rykiel Jr., E.J., Stahl, R.S., Wu, H., Schoolfield, R.M., 1995. A model comparison for daylength as a function of latitude and day of year. Ecol. Model. 80, 8795

Fourqurean, J.W., Duarte, C.M., Kennedy, H., Marba, N., Holmer, M., Mateo, M.A., Apostolaki, E.T., Kendrick, G.A., Krause-Jensen, D., McGlathery K.J., Serrano O., 2012. Seagrass ecosystems as a globally significant carbon stock. Nat. Geosci. 5, 505-509

Ganthy, F., Sottolichio, A., Verney, R., 2013. Seasonal modification of tidal flat sediment dynamics by seagrass meadows of Zostera noltii (Bassin d'Arcachon, France). J. Mar. Sys. 109-110, 233-240

Glé, C., Del Amo, Y., Sautour, B., Laborde, P., Chardy, P., 2007. Variability of nutrients and phytoplankton primary production in a shallow macrotidal coastal ecosystem (Arcachon Bay, France). Est. Coast. Shelf Sci. 76, 642-656

Huret, M., Sourisseau, M., Petitgas, P., Struski, C., Léger, F., Lazure, P., 2013. A multi-decadal hindcast of a physical-biogeochemical model and derived oceanographic indices in the Bay of Biscay. J. Marine Syst. 109-110, S77-S94

Jassby, A.D., Platt, T., 1976. Mathematical formulation of the relationship between photosynthesis and light for phytoplankton. Limnol. Oceanogr. 21, 540-547

Kombiadou, K., Ganthy, F., Verney, R., Plus, M., Sottolichio, A., 2014. Modelling the effects of Zostera noltei meadows on sediment dynamics: application to the Arcachon lagoon. Ocean Dynam. 64, 1499-1516

Kraemer, G.P., Mazzella, L., 1999. Nitrogen acquisition, storage, and use by the co-occurring Mediterranean seagrasses Cymodocea nodosa and Zostera noltii. Mar. Ecol. Prog. Ser. $183,95-103$

Lavesque, N., Blanchet, H., de Montaudouin, X., 2009. Development of a multimetric approach to assess perturbation of benthic macrofauna in Zostera noltii beds. J. Exp. Mar. Biol. Ecol. 368, 101-112

Lazure, P., Dumas, F., 2008. An external-internal mode coupling for a 3D hydrodynamical model for applications at regional scale (MARS). Adv. Wat. Resour. 31, 233-250

Lazure, P., Garnier, V., Dumas, F., Herry, C., Chifflet, M., 2009. Development of a hydrodynamic model of the Bay of Biscay. Validation of hydrology. Cont. Shelf Res. 29, 985-997 
Leuschner, C., Landwehr, S., Mehlig, U., 1998. Limitation of carbon assimilation of intertidal Zostera noltii and Z. marina by desiccation at low tide. Aquat. Bot. 62, 171- 176

Loyer, S., 2001. Modélisation de la production phytoplanctonique dans la zone côtière atlantique enrichie par les apports fluviaux. Thèse de Doctorat de l'Université de Paris VI, $232 \mathrm{pp}$.

L'Yavanc, J., 1995. Evolution bathymétrique et morphologique du Bassin d'Arcachon. Ifremer Report DEL 12-95 (in french), 82pp. Unpublished.

Marbá, N., Cebrián, J., Enríquez, S., Duarte, C.M., 1996. Growth patterns of Western Mediterranean seagrasses: species-specific responses to seasonal forcing. Mar. Ecol. Prog. Ser. 133, 203-215

Mascaró, O., Romero, J., Pérez, M., 2014. Seasonal uncoupling of demographic processes in a marine clonal plant. Estuar. Coast. Shelf Science. 142, 23-31.

Massa, S.I., Arnaud-Haond, S., Pearson, G.A., Serrão, E.A., 2009. Temperature tolerance and survival of intertidal populations of the seagrass Zostera noltii (Hornemann) in Southern Europe (Ria Formosa, Portugal). Hydrobiol. 619, 195-201

Montefalcone, M., Vassallo, P., Gatti, G., Parravicini, V., Paoli, C., Morri, C., Bianchi, C.N., 2015. The exergy of a phase shift: ecosystem functioning loss in seagrass meadows of the Mediterranean Sea. Estuar. Coast. Shelf Science. 156, 186-194

Ouisse, V., Migné, A., Davoult, D., 2010. Seasonal variations of community production, respiration and biomass of different primary producers in an intertidal Zostera noltii bed (Western English Channel, France). Hydrobiol. 649, 3-11

Ouisse, V., Migné, A., Davoult, D., 2011. Community-level carbon flux variability over a tidal cycle in Zostera marina and Z. noltii beds. Mar. Ecol. Prog. Ser. 437, 79-87

Ouisse, V., Migné, A., Davoult, D., 2014. Comparative study of methodologies to measure in situ the intertidal benthic community metabolism during immersion. Estuar. Coast. Shelf Science. 136, 19-25.

Peralta, G., Brun, F.G., Hernández, I., Vergara, J.J., Pérez-Lloréns, J.L., 2005. Morphometric variations as acclimation mechanisms in Zostera noltii beds. Est. Coast. Shelf Sci. 64, $347-356$

Pérez-Lloréns, J.L., Niell, F.X., 1993. Seasonal dynamics of biomass and nutrient content in the intertidal seagrass Zostera noltii Hornem. from Palmones River estuary, Spain. Aquat. Bot. 46, 49-66

Philippart, C.J.M, 1995. Seasonal variation in growth and biomass of an intertidal Zostera noltii stand in the Dutch Wadden Sea. Neth. J. Sea Res. 33, 205-218 
Pinardi, M., Bartoli, M., Longhi, D., Marzocchi, U., Laini, A., Ribaudo C., Viaroli, P., 2009. Benthic metabolism and denitrification in a river reach: a comparison between vegetated and bare sediments. J Limn. 68(1), 133-145

Plus, M., Deslous-Paoli, J-M., Auby, I., Dagault, F., 2001. Factors influencing primary production of seagrass beds (Zostera noltii Hornem.) in the Thau lagoon (French Mediterranean coast). J. Exp. Mar. Biol. Ecol. 259, 63-84

Plus, M., Chapelle, A., Ménesguen, A., Deslous-Paoli, J-M., Auby, I., 2003. Modelling seasonal dynamics of biomasses and nitrogen contents in a seagrass meadow (Zostera noltii Hornem.): application to the Thau lagoon (French Mediterranean coast). Ecol. Model. $161,213-238$

Plus, M., Auby, I., Verlaque, M., Levavasseur, G., 2005. Seasonal variations in photosynthetic irradiance response curves of macrophytes from a Mediterranean coastal lagoon. Aquat. Bot. 81, 157-173

Plus, M., Dumas, F., Stanisière, J., Maurer, D., 2009. Hydrodynamic characterization of the Arcachon Bay, using model-derived descriptors. Cont. Shelf Res. 29, 1008-1013

Plus, M., Dalloyau, S., Trut, G., Auby, I., de Montaudouin, X., Emery, E., Noël, C., Viala, C., 2010. Long-term evolution (1988-2008) of Zostera spp. meadows in Arcachon Bay (Bay of Biscay). Est. Coast. Shelf Sci. 87, 357-366

Polsenaere, P., Lamaud, E., Lafon, V., Bonnefond, J.-M., Bretel, P., Delille, B., Deborde, J., Loustau, D., Abril, G., 2012. Spatial and temporal $\mathrm{CO}_{2}$ exchanges measured by Eddy Covariance over a temperate intertidal flat and their relationships to net ecosystem production. Biogeosci. 9, 249-268

R Core Team, 2014. R: A language and environment for statistical computing. R Foundation for Statistical Computing, Vienna, Austria. URL http://www.R-project.org/.

Ribaudo, C., Bartoli, M., Racchetti, E., Longhi, D., Viaroli, P., 2011. Seasonal fluxes of $\mathrm{O}_{2}$, DIC and $\mathrm{CH}_{4}$ in sediments with Vallisneria spiralis: indications for radial oxygen loss. Aquat. Bot. 94, 134-142

Sand-Jensen, K., 1975. Biomass, net production and growth dynamics in an eelgrass (Zostera marina L.) population in Vellerup Vig, Denmark. Ophelia 14, 185-201

Soriano-Serra, E-J., 1992. Etude écologique des marais salés du Bassin d'Arcachon: structure et évolution des schorres, production et dégradation de leur végétation et échanges de matières particulaires entre les schorres et le bassin. Thèse de Doctorat. Université Bordeaux 1. 
Valle, M., Chust, G., del Campo, A., Wisz, M. S., Olsen, S. M., Garmendia, J. M., Borja, A., 2014. Projecting future distribution of the seagrass Zostera noltii under global warming and sea level rise. Biol. Conserv. 170, 74-85

van Lent, F., Nienhuis, P.H., Verschuure, J.M., 1991. Production and biomass of the seagrasses

Zostera noltii Hornem. and Cymodocea nodosa (Ucria) Aschers. at the Banc d'Arguin

(Mauritania, NW Africa): a preliminary approach. Aquat. Bot. 41, 353-367

Vermaat, J.E., Hootsmans, M.J.M., Nienhuis, P.H., 1987. Seasonal dynamics and leaf growth of Zostera noltii Hornem., a perennial intertidal seagrass. Aquat. Bot. 28, 287-285

Vermaat, J.E., 2009. Linking clonal growth patterns and ecophysiology allows the prediction of meadow-scale dynamics of seagrass beds. Perspect. Plant Ecol. Evol. Syst.11, 137-155

Viaroli, P., Bartoli, M., Giordani, G., Naldi, M., Orfanidis, S., Zaldivar, J.M., 2008.

Community shifts, alternative stable states, biogeochemical controls and feedbacks in eutrophic coastal lagoons: a brief overview. Aquat. Conserv. 18, 105-117

Welsh, D.T., Bartoli, M., Nizzoli, D., Castaldelli, G., Riou, S., Viaroli, P., 2000. Denitrification, nitrogen fixation, community primary productivity and inorganic-N and oxygen fluxes in an intertidal Zostera noltii meadow. Mar. Ecol. Prog. Ser. 208, 67-77

Zieman, J.C., 1974. Methods for the study of the growth and production of the turtlegrass, Thalassia testudinum König. Aquacult. 4, 139-143 


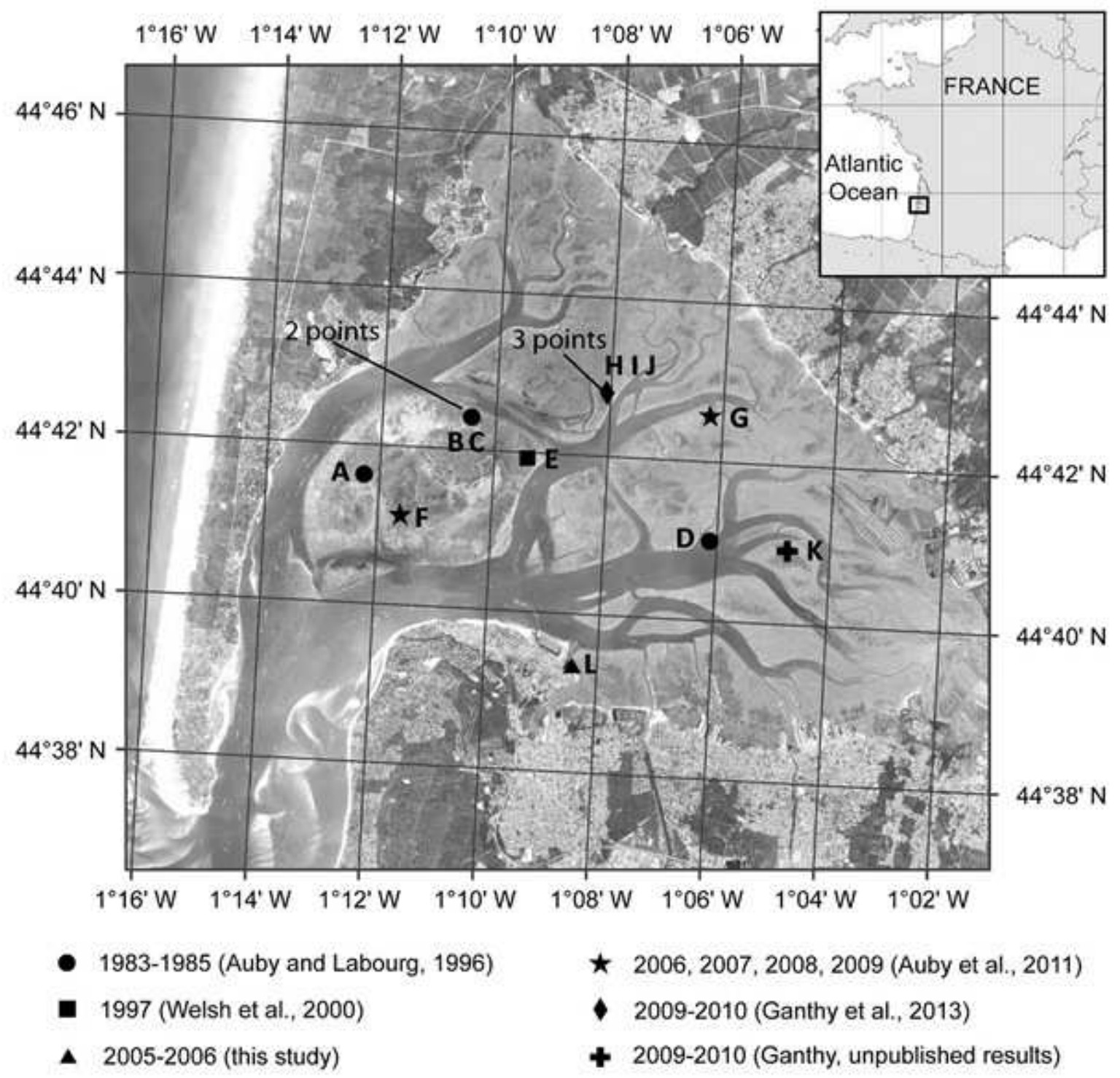




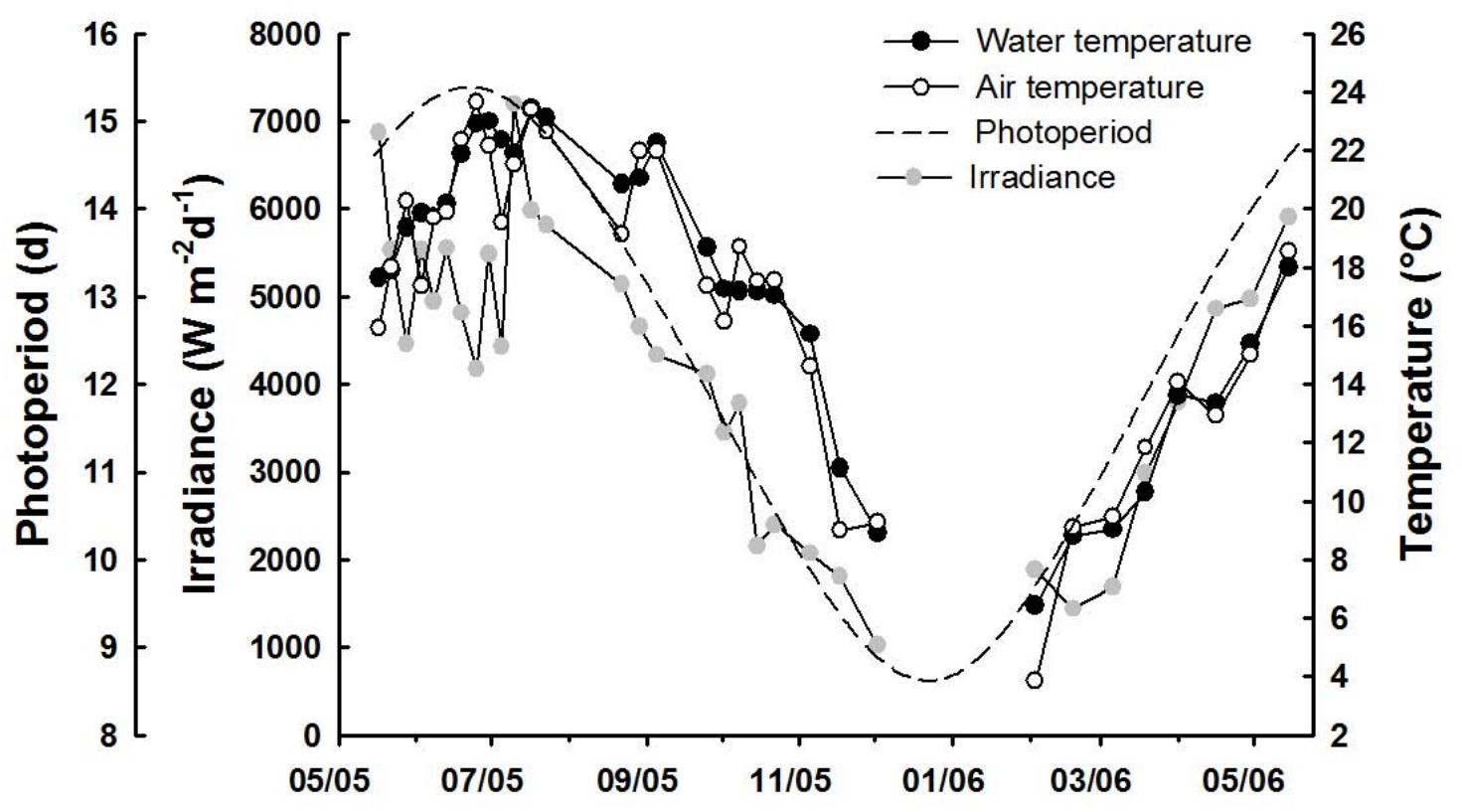




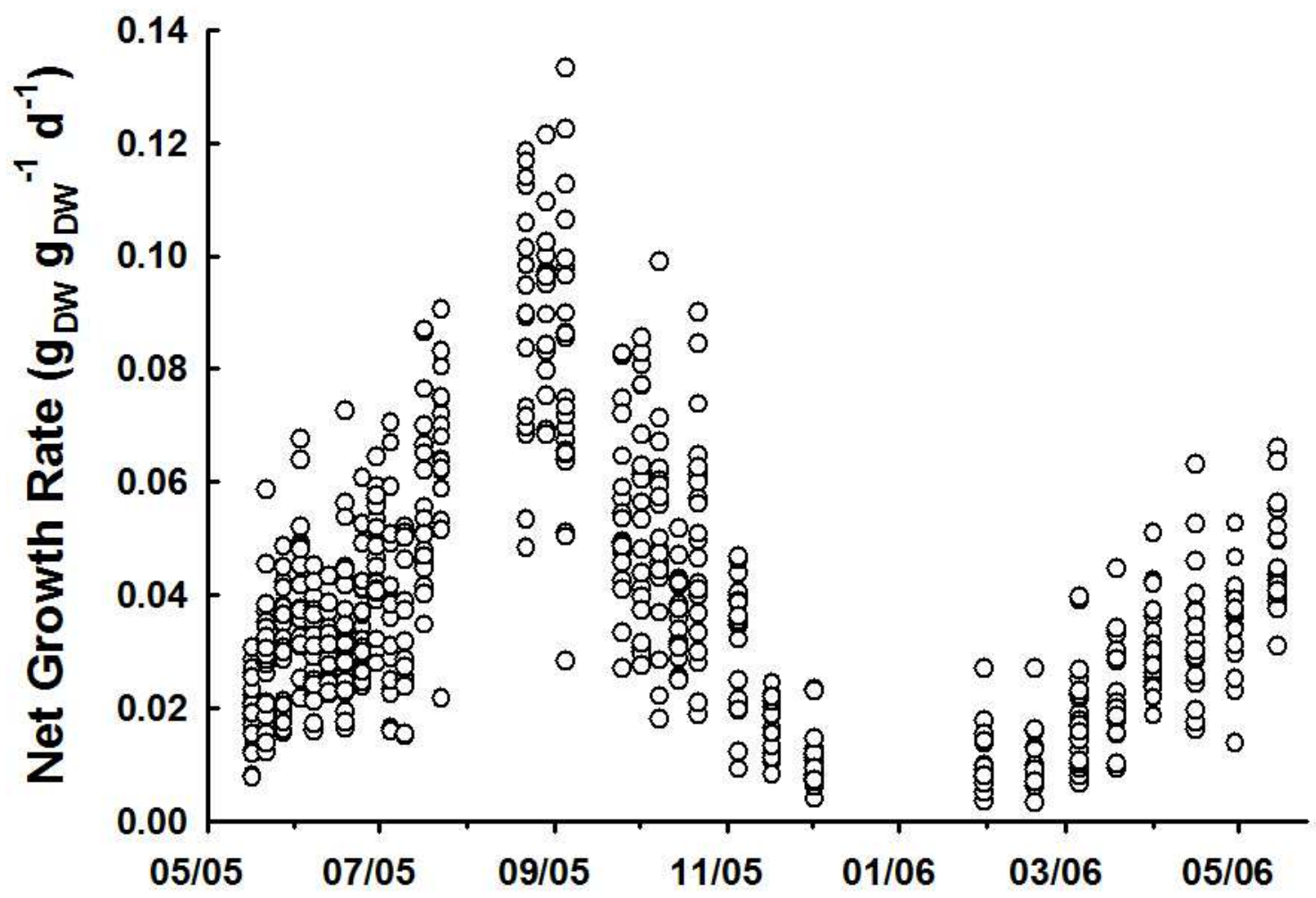




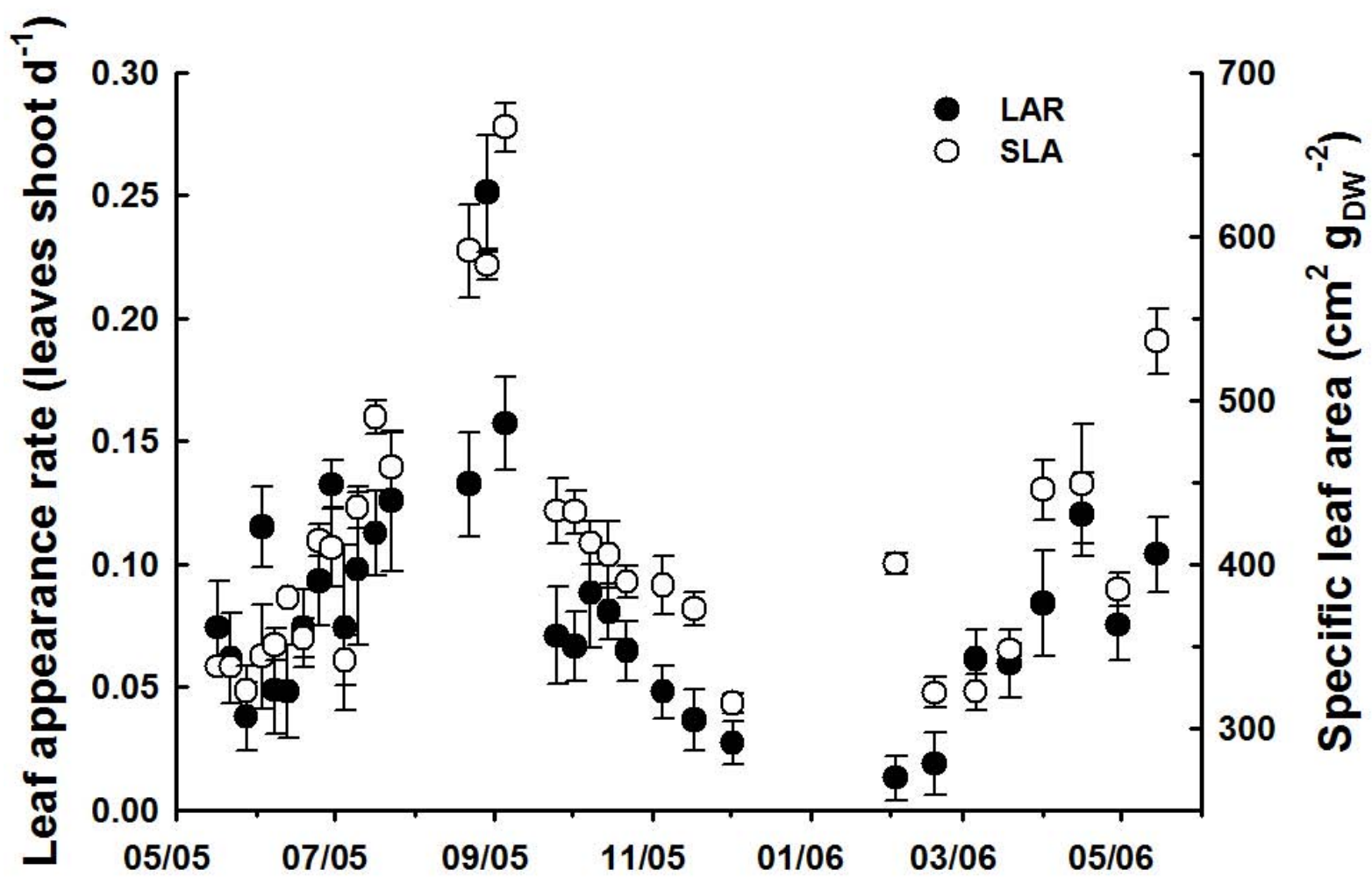



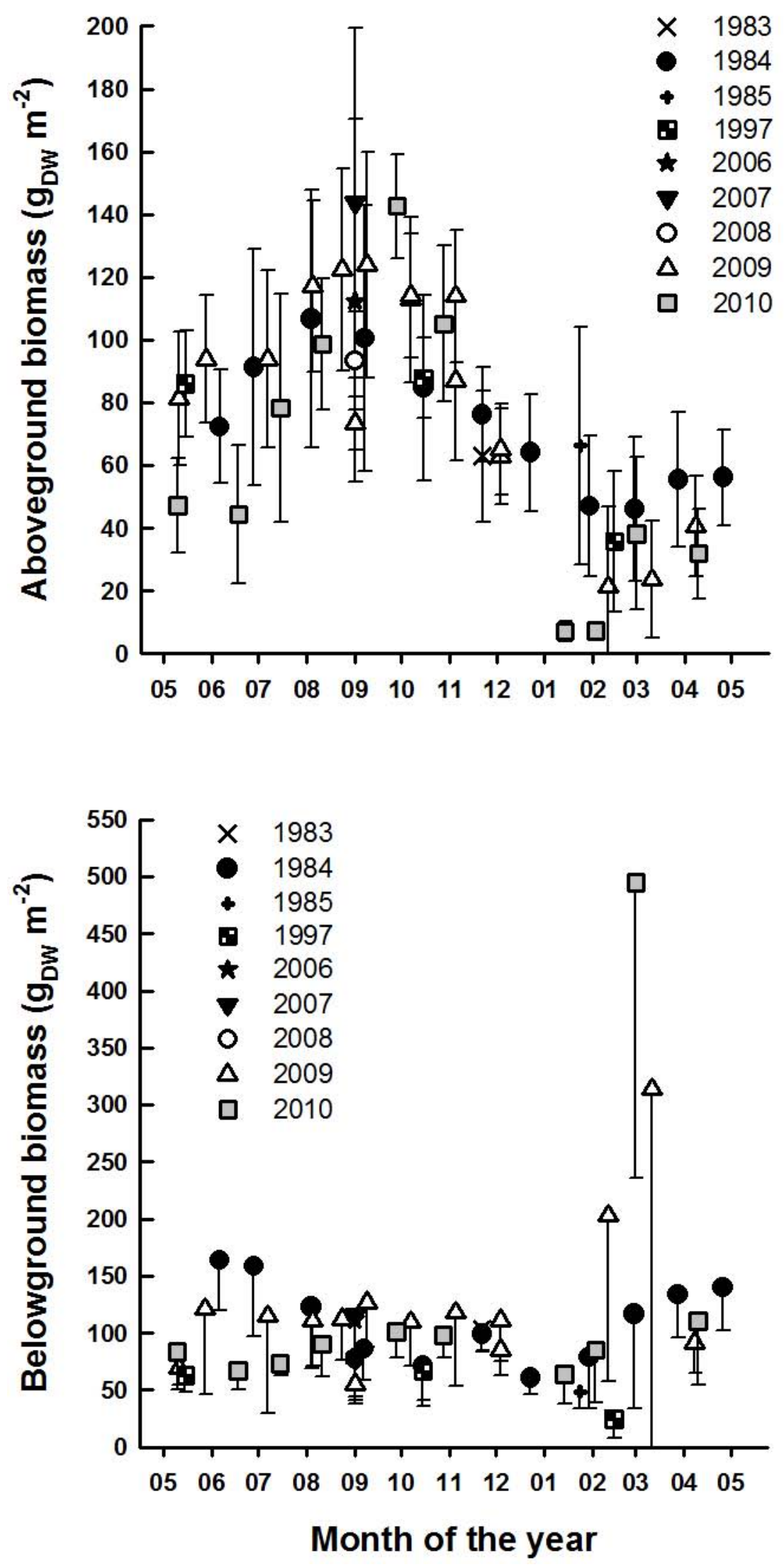


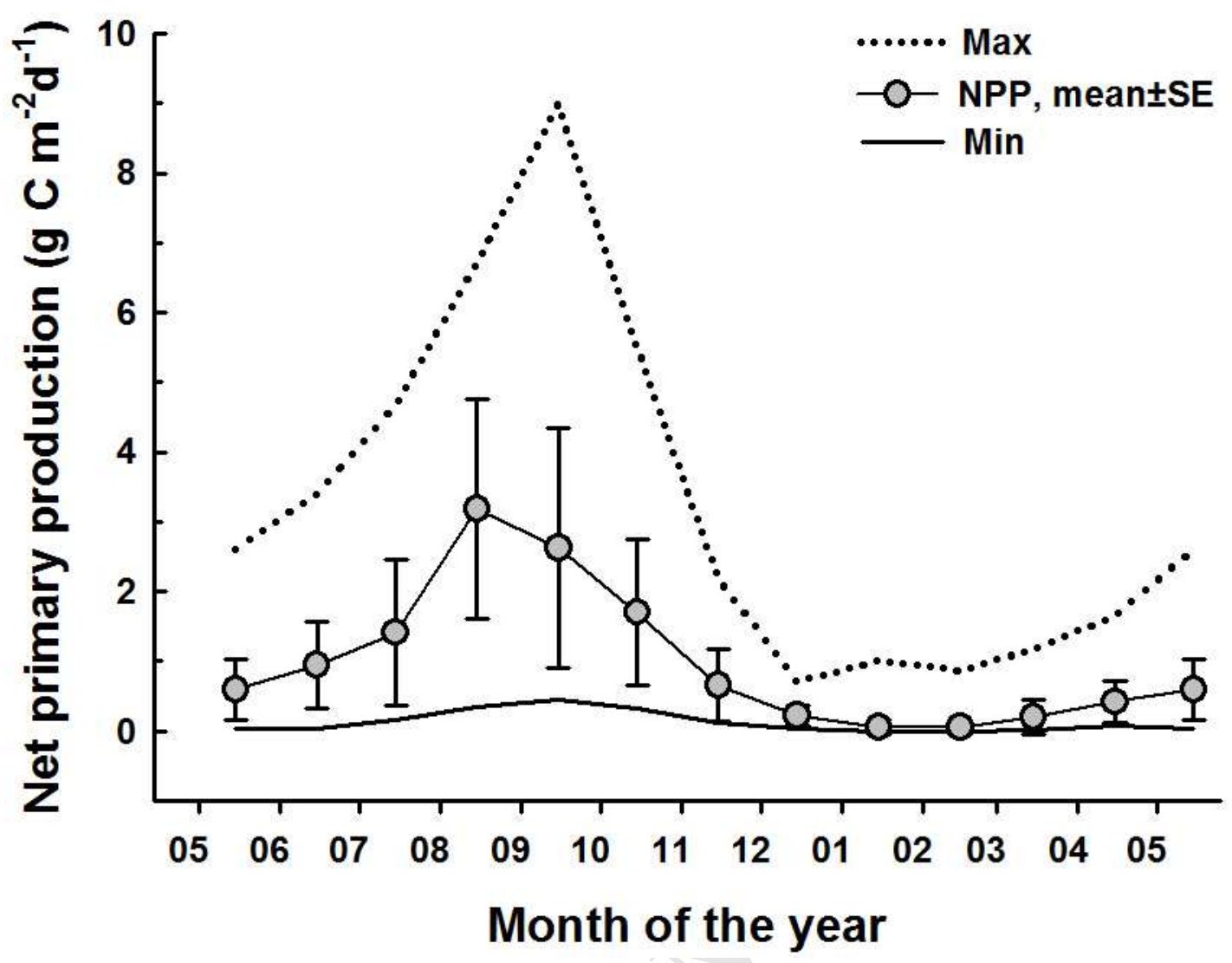



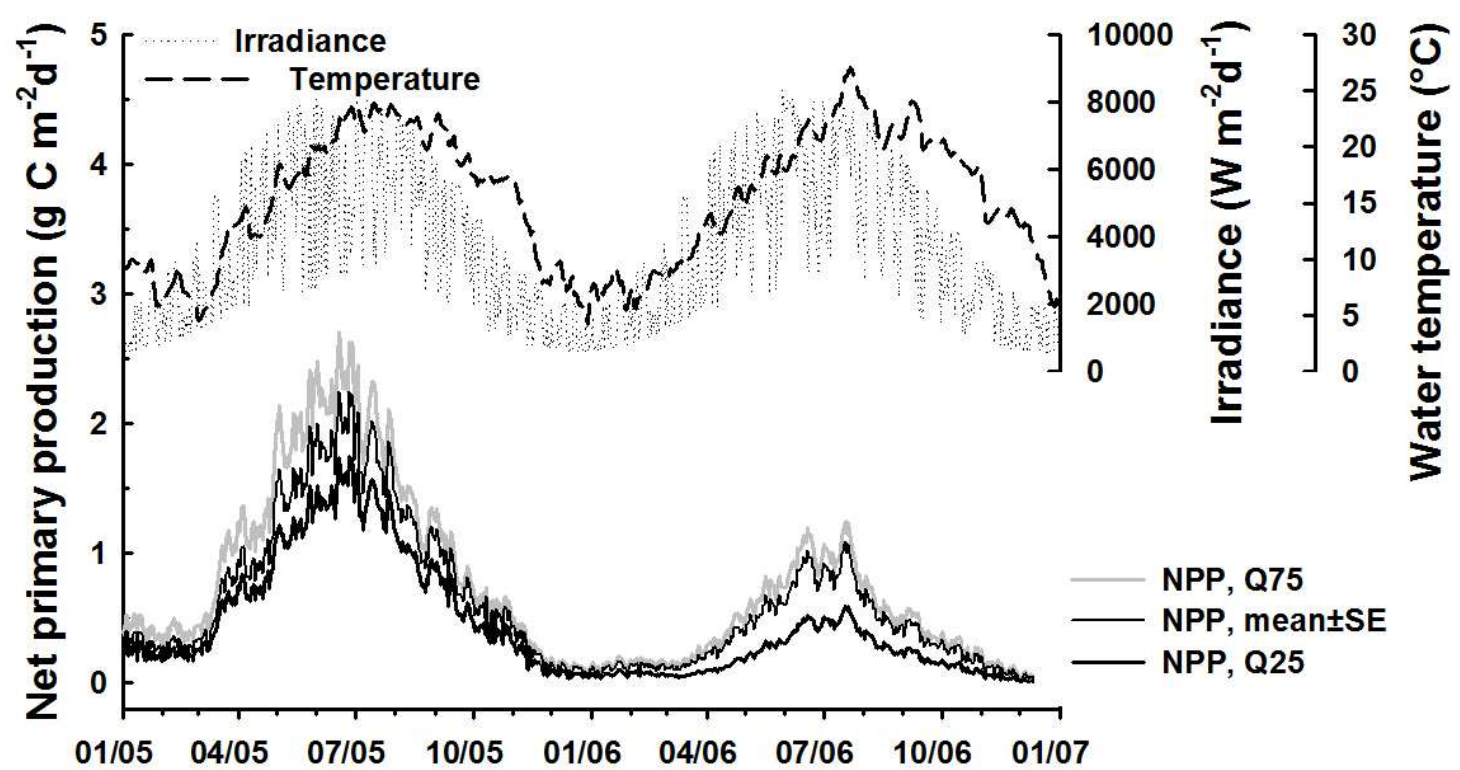